\title{
RESENSI PUISI KONTEMPLASI KREASI AGUNG PURNOMO
}

\author{
Bella Silvia
}

Universitas Nahdlatul Ulama Sidoarjo

\section{PENGANTAR}

Resensi puisi dikenal sebagai ulasan di mana Anda harus memberikan interpretasi puisi yang sangat pribadi, dan menggambarkan makna simbolis dari kata-kata, frasa, dan gambar yang disajikan dalam puisi itu. Adalah umum bagi seseorang untuk berbagi pemikiran dan kesan tentang apa yang telah dia baca. Terkadang buku atau puisi yang sama menghasilkan kesan yang berlawanan pada pembaca yang berbeda. Ulasan atau resensi adalah pertukaran tayangan tentang buku, dan ekspresi sikapnya terhadap gambar yang dibuat oleh penulis (Answershark, 2019). "Lima W dan Satu H" atau 5W1H itu - yang pada umumnya digunakan sebagaimana kita menulis ulasan puisi. Begitulah cara kita belajar menulis berita di kampus, dan bagaimana kita belajar menulis ulasan musik dan 
fiksi pertama dan kemudian ulasan puisi (Young, 2015).

\section{AGUNG PURNOMO}

Agung Purnomo adalah salah satu penulis dan dosen produktif di Indonesia. Ia lahir di Sidoarjo, 3 November 1981. Semenjak menjadi dosen, ia mulai giat dalam menulis publikasi. Karya-karyanya pernah dimuat di beberapa penerbit nasional, seperti : UNUSIDA Press, ITB Press dan STIEBA Madura Press.

\section{KREASI}

Ada beberapa judul puisi karya Agung Purnomo yang akan memanjakan pembaca, yaitu : sepekan awal tanpamu, cantik, berpulang, bapak Samsuri, menyala, tangisnya, pandai, rindu di ubunubun, kita, dua kaki dan \#CH1. Resolusi puisi dalam buku ini sangat tepat diberikan kepada pemuda yang membutuhkan inspirasi. Karya sastra sederhana namun menggunakan teknik untuk menunjukkan beragam jenis puisi di dunia. Bahasa puisi karya 
Agung Purnomo tergolong mudah dipahami, namun memiliki makna yang dalam.

\section{SEPEKAN AWAL TANPAMU}

\begin{tabular}{|l|l|}
\hline Identitas Buku & \multicolumn{1}{c|}{ Keterangan } \\
\hline Judul Puisi & Sepekan Awal Tanpamu \\
\hline Penulis & Agung Purnomo, Nur Asitah \\
\hline Jenis Puisi & Puisi bersekuen \\
\hline Judul Buku & Arebhan Helai \\
\hline Penerbit & STIEBA Madura Press \\
\hline Tahun & 2019 \\
\hline ISBN & $978-623-90413-3-5$ \\
\hline
\end{tabular}

Dalam buku berjudul Arebhan Helai dengan puisi berjudul Sepekan Awal Tanpamu ini Agung Purnomo menggandeng Nur Asitah berusaha menyampaikan aktivitas harian seseorang dalam seminggu yang menjalani perpisahan dengan seseorang spesial. Puisi dimulai hari senin hingga hari minggu menggunakan teknik puisi bersekuen (Purnomo \& Asitah, 2019d). 


\section{CANTIK}

\begin{tabular}{|l|l|}
\hline Identitas Buku & \multicolumn{1}{c|}{ Keterangan } \\
\hline Judul Puisi & Cantik \\
\hline Penulis & Agung Purnomo, Nur Asitah \\
\hline Jenis Puisi & Puisi Jenaka Limerick \\
\hline Judul Buku & Lembhar Jiwana \\
\hline Penerbit & STIEBA Madura Press \\
\hline Tahun & 2019 \\
\hline ISBN & $978-623-90413-2-8$ \\
\hline
\end{tabular}

Puisi berjudul Cantik dalam buku Lembhar Jiwana tersebut mengisahkan kecantikan seseorang. Namun ternyata bukan seorang pria. Penulis Agung Purnomo dan Nur Asitah memakai teknik puisi jenaka Limerick untuk menggali puisi (Purnomo \& Asitah, 2019b).

\section{BERPULANG}

\begin{tabular}{|l|l|}
\hline Identitas Buku & \multicolumn{1}{|c|}{ Keterangan } \\
\hline Judul Puisi & Berpulang \\
\hline Penulis & Agung Purnomo \\
\hline Jenis Puisi & Puisi Epitaf \\
\hline Judul Buku & Syair Nimala \\
\hline Penerbit & STIEBA Madura Press \\
\hline Tahun & 2019 \\
\hline ISBN & $978-623-90413-1-1$ \\
\hline
\end{tabular}


Puisi karya Agung Purnomo ini yang berjudul Berpulang dalam buku bertajuk Syair Nimala ini mengisahkan perjalanan anak manusia menghadap sang Pencipta. Penulis memakai teknik puisi Epitaf yang biasa diberikan untuk orang meninggal (Purnomo, 2019a).

\section{BAPAK SAMSURI}

\begin{tabular}{|l|l|}
\hline Identitas Buku & \multicolumn{1}{c|}{ Keterangan } \\
\hline Judul Puisi & Bapak Samsuri \\
\hline Penulis & Agung Purnomo, Nur Asitah \\
\hline Jenis Puisi & Puisi Clerihew \\
\hline Judul Buku & Dhalubang Marta \\
\hline Penerbit & STIEBA Madura Press \\
\hline Tahun & 2019 \\
\hline ISBN & $978-623-90413-0-4$ \\
\hline
\end{tabular}

Kedua penulis ingin mengungkapkan bahwa mengasosiasikan antara seorang bapak dengan hewan kucing. Puisi menggunakan teknik Clerihew untuk menyampaikan pesan kepada pembaca (Purnomo \& Asitah, 2019a). 
MENYALA

\begin{tabular}{|l|l|}
\hline Identitas Buku & \multicolumn{1}{c|}{ Keterangan } \\
\hline Judul Puisi & Menyala \\
\hline Penulis & Agung Purnomo \\
\hline Jenis Puisi & Puisi Haiku \\
\hline Judul Buku & Tenta Kimaya \\
\hline Penerbit & STIEBA Madura Press \\
\hline Tahun & 2019 \\
\hline ISBN & $978-602-53090-9-0$ \\
\hline
\end{tabular}

Puisi dalam buku Tenta Kimaya yang berjudul menyala lebih menitikberatkan pada proses kerja menggunakan gawai untuk mencapai target tugas. Jika dibaca secara keseluruhan, puisi ini sangat menarik dan sesuai dengan rutinitas masyarakat dalam berbagai versi atau pandangan penulis dan pembaca. Puisi memakai teknik Haiku dengan formula khusus khas bangsa Jepang (Purnomo, 2019b).

\section{TANGISNYA}

\begin{tabular}{|l|l|}
\hline Identitas Buku & \multicolumn{1}{|c|}{ Keterangan } \\
\hline Judul Puisi & Tangisnya \\
\hline Penulis & Agung Purnomo, Nur Asitah \\
\hline Jenis Puisi & Puisi Naratif \\
\hline Judul Buku & Bhumi Bawera \\
\hline Penerbit & STIEBA Madura Press \\
\hline Tahun & 2019 \\
\hline ISBN & $978-602-53090-8-3$ \\
\hline \multicolumn{2}{|c|}{6}
\end{tabular}


Mencengkeramai buku sajak bertajuk Tangisnya dalam buku Bhumi Bawera karya kolaborasi Agung Purnomo dan Nur Asitah, membangun banyak kesan dan rasa yang ingin disampaikan. Paragraf disusun beralur sesuai khas puisi naratif sehingga enak untuk dicerna (Purnomo \& Asitah, 2019e).

\section{PANDAI}

\begin{tabular}{|l|l|}
\hline Identitas Buku & \multicolumn{1}{c|}{ Keterangan } \\
\hline Judul Puisi & Pandai \\
\hline Penulis & Agung Purnomo, Nur Asitah \\
\hline Jenis Puisi & Puisi Riddle \\
\hline Judul Buku & Tolesan Aditi \\
\hline Penerbit & STIEBA Madura Press \\
\hline Tahun & 2019 \\
\hline ISBN & $978-602-53090-7-6$ \\
\hline
\end{tabular}

Maka begitulah sang penulis Agung Purnomo dan Nur Asitah berusaha menghadirkan rasa penasaran kepada pembaca dengan pertanyaan khas puisi Riddle. Isi puisi yang ada mampu menggambarkan jelas apa yang diinginkan oleh penulis karena dekat dengan keseharian kita. Penulis berusaha keras menyoroti kondisi masyarakat modern dengan puisi (Purnomo \& Asitah, 2019c). 


\section{RINDU DI UBUN-UBUN}

\begin{tabular}{|l|l|}
\hline Identitas Buku & \multicolumn{1}{c|}{ Keterangan } \\
\hline Judul Puisi & Rindu di Ubun-ubun \\
\hline Penulis & Agung Purnomo \\
\hline Jenis Puisi & Puisi Bebas \\
\hline Judul Buku & Rassana Jlantir \\
\hline Penerbit & STIEBA Madura Press \\
\hline Tahun & 2019 \\
\hline ISBN & $978-602-53090-6-9$ \\
\hline
\end{tabular}

Penulis Agung Purnomo terlihat ingin menunjukkan puisi menarik dari susunan teks di kertas. Dari segi isi puisi tersebut menggambarkan sebuah renungan dirinya tentang kerinduan. Dari cara penyair memaparkan isi hatinya, puisi Rindu di Ubunubun sangat tepat bila digolongkan pada aliran ekspresionisme (Purnomo, 2019c).

\section{KITA}

\begin{tabular}{|l|l|}
\hline Identitas Buku & \multicolumn{1}{c|}{ Keterangan } \\
\hline Judul Puisi & Kita \\
\hline Penulis & Agung Purnomo, Elsa Rosyidah \\
\hline Jenis Puisi & Puisi Bebas \\
\hline Judul Buku & Suweda Ate \\
\hline Penerbit & STIEBA Madura Press \\
\hline Tahun & 2019 \\
\hline ISBN & $978-602-53090-5-2$ \\
\hline
\end{tabular}


Puisi berjudul Kita mengangkat tema tentang perbedaan antara dua anak manusia. Namun, ditutup dengan keindahan antara perbedaan tersebut. Saling mengisi dan memberi kebahagiaan satu sama lain (Purnomo \& Rosyidah, 2019).

\section{DUA KAKI}

\begin{tabular}{|l|l|}
\hline Identitas Buku & \multicolumn{1}{c|}{ Keterangan } \\
\hline Judul Puisi & Dua Kaki \\
\hline Penulis & Agung Purnomo \\
\hline Jenis Puisi & Puisi Bebas \\
\hline Judul Buku & Kidung Nawala (Jilid 2) \\
\hline Penerbit & UNUSIDA Press \\
\hline Tahun & 2018 \\
\hline ISBN & $978-602-51116-8-6$ \\
\hline
\end{tabular}

Puisi ini menceritakan tentang kejadian kondisi kebingungan sang penulis di dua dunia. Penulis sering diharuskan untuk memilih atas suatu pilihan. Melalui puisi di buku Kidung Nawala (jilid 2) ini kita bisa melihat apa dan bagaimana aliran perjalanan hidup. Tak hanya sekedar hiburan. Pilihan ini bisa menjadi cermin bagi mereka yang juga tengah mengaliri sungai kehidupan yang berliku dan bergelombang ini (Purnomo, 2018b). 


\section{\#CH1}

\begin{tabular}{|l|l|}
\hline Identitas Buku & \multicolumn{1}{|c|}{ Keterangan } \\
\hline Judul Puisi & \#CH1 \\
\hline Penulis & Agung Purnomo \\
\hline Jenis Puisi & \\
\hline Judul Buku & Kidung Nawala (Jilid 1) \\
\hline Penerbit & UNUSIDA Press \\
\hline Tahun & 2018 \\
\hline ISBN & $978-602-51116-7-9$ \\
\hline
\end{tabular}

Puisi diatas mengangkat tema mengenang kepergian kiper legendaris Persela Lamongan yang meninggal ketika bertanding (Purnomo, 2018a).

\section{PENUTUP}

Puisi-puisi karya Agung Purnomo tergolong mudah dipahami, ringan, namun memiliki makna yang dalam bagi pembacanya. 


\section{REFERENCES}

Answershark. (2019). How to Write a Poetry Review.

Retrieved June 23, 2019, from

https://answershark.com/writing/creating-

review/how-to-write-poetry-review.html

Purnomo, A. (2018a). \#CH1. In Kidung Nawala (Jilid

1). Sidoarjo: UNUSIDA Press.

Purnomo, A. (2018b). Dua Kaki. In Kidung Nawala

(Jilid 2). Sidoarjo: UNUSIDA Press.

Purnomo, A. (2019a). Berpulang. In Syair Nimala.

Sumenep: STIEBA Madura Press.

Purnomo, A. (2019b). Menyala. In Tenta Kimaya.

Sumenep: STIEBA Madura Press.

Purnomo, A. (2019c). Rindu di Ubun-Ubun. In

Rassana Jlantir. Sumenep: STIEBA Madura

Press.

Purnomo, A., \& Asitah, N. (2019a). Bapak Samsuri.

In Dhalubang Marta. Sumenep: STIEBA

Madura Press.

Purnomo, A., \& Asitah, N. (2019b). Cantik. In

Lembhar Jiwana. Sumenep: STIEBA Madura

Press.

Purnomo, A., \& Asitah, N. (2019c). Pandai. In

Tolesan Aditi. Sumenep: STIEBA Madura Press.

Purnomo, A., \& Asitah, N. (2019d). Sepekan Awal

Tanpamu. In Arebhan Helai. Sumenep: STIEBA

Madura Press.

Purnomo, A., \& Asitah, N. (2019e). Tangisnya. In

Bhumi Bawera. Sumenep: STIEBA Madura

Press. 
Purnomo, A., \& Rosyidah, E. (2019). Kita. In Suweda Ate. Sumenep: STIEBA Madura Press.

Young, G. (2015). How to Write a Poetry Review.

Retrieved June 22, 2019, from

https://www.tweetspeakpoetry.com/2015/07/21/

how-to-write-a-poetry-review/ 